\title{
Relative condition factor, length-weight relationship, and growth of three-spotted flounder, Pseudorhombus triocellatus from Parangipettai Coast, India
}

\author{
PALANIVEL BHARADHIRAJAN ${ }^{1, \boldsymbol{v}}$, GOPALAN MAHADEVAN ${ }^{1}$, PERUMAL MURUGESAN $^{1}$, SAMANTHAM \\ MURUGAN ${ }^{1}$, MOJTABA POULADI ${ }^{2}$, REZA ABBASPOUR NADERI ${ }^{3}$ \\ ${ }^{1}$ Centre of Advanced Study in Marine Biology, Faculty of Marine Sciences, Annamalai University, Parangipettai-608 502, Tamil Nadu, India. \\ Tel: +91-9788597210, ` email: bharadhicas@gmail.com \\ ${ }^{2}$ Department of Fisheries, Faculty of Fisheries and Environmental Sciences, Gorgan University of Agricultural Sciences and Natural Resources. Gorgan, \\ Golestan, Iran \\ ${ }^{3}$ Department of Capture Fisheries, Iranian Fisheries Research Organization, Tehran, Iran
}

Manuscript received: 25 December 2018. Revision accepted: 15 January 2019

\begin{abstract}
Bharadhirajan P, Mahadevan G, Murugesan P, Murugan S, Pouladi M, Abbaspour Naderi R. 2019. Relative condition factor, length-weight relationship, and growth of three-spotted flounder, Pseudorhombus triocellatus (Bloch \& Schneider, 1801) from Parangipettai Coast, India. Biodiversitas 20: 373-379. The three-spotted flounder, Pseudorhombus triocellatus is usually caught as trawl by-catch from Parangipettai coastal waters but regrettably, limited information on its age structure and growth is available. Hence, the present study aims to understand some basic parameters of its biology and growth. A total of 759 specimens (360 males and 399 females) ranging from $4 \mathrm{~cm}$ to $13 \mathrm{~cm}$ in total length (TL) and 5.26-35.41 g in weight were collected from the trawl catches of Parangipettai and Mudasalodai landing center during January-December 2015. The estimated growth coefficient (b) value for males (2.797) was greater than 3 and for females (3.023) was less than 3. The relative condition factor (Kn) values of females were higher than males except during February, June, and September. The values of asymptotic length (L $\infty$ ) obtained in this study using various methods didn't vary significantly $(\mathrm{P}>0.05)$. The most appropriate values of asymptotic length $(\mathrm{L} \alpha)$ for males were $137.11 \mathrm{~mm}$ and for females were $141.75 \mathrm{~mm}$. The most appropriate values of growth rate $(\mathrm{K})$ for males were $0.397 \mathrm{yr}^{-1}$ and for females were $0.410 \mathrm{yr}^{-1}$. The estimated length at age $0\left(\mathrm{t}_{0}\right)$ for males and females were $0.197 \mathrm{~mm}$ and $0.292 \mathrm{~mm}$, respectively. The longevity $\left(\mathrm{t}_{\mathrm{max}}\right)$ of males and females P. triocellatus were 2.04 years and 2.24 years, respectively. The result of this study provides basic information for future studies.
\end{abstract}

Keywords: Condition factor, growth, India, length-weight, Parangipettai, Pseudorhombus triocellatus

\section{INTRODUCTION}

Studies on length-weight relationships have important implications for fisheries science and are necessary for stock assessment models (Mendes et al. 2004). They are commonly used in the ecosystem modeling (Christensen and Walters 2004) to calculate the production over biomass ratio $(\mathrm{P} / \mathrm{B})$ of different functional groups used for more precise weight estimates. Length-weight relationships help in estimating the weight of a fish of a given length and can be used in studies of gonad development, the rate of feeding, metamorphosis, maturity, and condition (Richter et al. 2000). This relationship is also important in estimating the average weight at a given length group and in assessing the relative well-being of a fish population (Oscoz et al. 2005; Abowei et al. 2009).

Age and growth studies are necessary when dealing with population dynamics, fishery forecasts and fishery surveys (Laidig et al. 2003). Mohanraj (2000) stated that a better understanding of growth-size and age relationship is important for applying equilibrium yield models in the fishery management. Data on age and growth of fishes are indispensable for the understanding of biological traits (e.g. lifespan, age at sexual maturity etc.) and the study of population demographic structure and its dynamics (Panfili et al. 2002). Age and growth data also permit the determination of population changes due to fishing activities.

The analysis of length frequency data is a reliable method of obtaining age and growth parameters of fishes. Many computer-assisted methods exist for the analysis of length-frequency data of fish and shellfish such as LFSA (Sparre 1987), COMPLEAT ELEFAN (Gayanilo et al. 1988), MULTIFAN (Fournier et al. 1990), LFDA (Kirkwood et al. 2001) and FiSAT (Gayanilo and Pauly 1997). The ELEFAN procedure is widely used, because it is presented in a user-friendly format, demands little processing power it does not require normality in the distribution of the data set used and the theory behind it is easy to understand.

The three-ring flounder, $P$. triocellatus, is a member of the family Paralichthyidae and is widely distributed throughout the Indo-West Pacific, from the Red Sea and East Africa to Japan and New Caledonia. In India, generally, this fish has low market value and are considered as by-catch fish (Sujatha 1995; Bijukumar and Deepthi 2009). P. triocellatus breeds once a year and eggs are released in a single batch in Tuticorin coastal waters and its Spawning period extends from August to October 
(Ramanathan et al. 1990). This fish is commonly found in clay, sand and mud bottom habitats of the continental shelf and it generally predates on benthic fauna. They are caught by using a different variety of gears including trawlers (Ramanathan et al. 1990). The information on the biology of $P$. triocellatus is limited and hence the length-weight relationship, relative condition factor, and growth of $P$. triocellatus was estimated from Parangipetai coastal waters in the present study.

\section{MATERIALS AND METHODS}

\section{Study area and data collection}

The Parangipettai coastal water of Tamil Nadu, India is divided into two major fish landing centers; namely Parangipettai (Annankoil) and Mudasalodai. Mudasalodai (Lat. 11 29'00.33' 'N; Log. 79 46'28.17' 'E) fish landing center has been selected for the present study as it is the only trawl landing center. Parangipettai (Lat. 11 30'08.03'’N; Log. 79 46'18.44'’E) landing center support maximum landing in pelagic marine fishes. These two landing centers are situated in the banks of VellarColeroon estuarine backwater complex (Figure 1).

For the study on the length-weight relationship, specimens of $P$. triocellatus were collected monthly from the trawl catches of Parangipettai and Mudasalodai landing center during January-December 2015. A total of 759 specimens (360 males and 399 females) ranging from $4 \mathrm{~cm}$ to $13 \mathrm{~cm}$ (TL) size were collected for this study; however, no sampling was done in May due to fishing holiday declared by the government. Male and female individuals were identified by examining the gonads by cutting the body cavity. The total length (TL) of both males and females were measured separately to the nearest millimeter (Figure 2). Weight (W) of both males and females were also measured separately by an electronic balance (accuracy $0.01 \mathrm{~g}$ ) after draining the water from the buccal cavity and wiping the moisture content on the body of fish (King 1996).

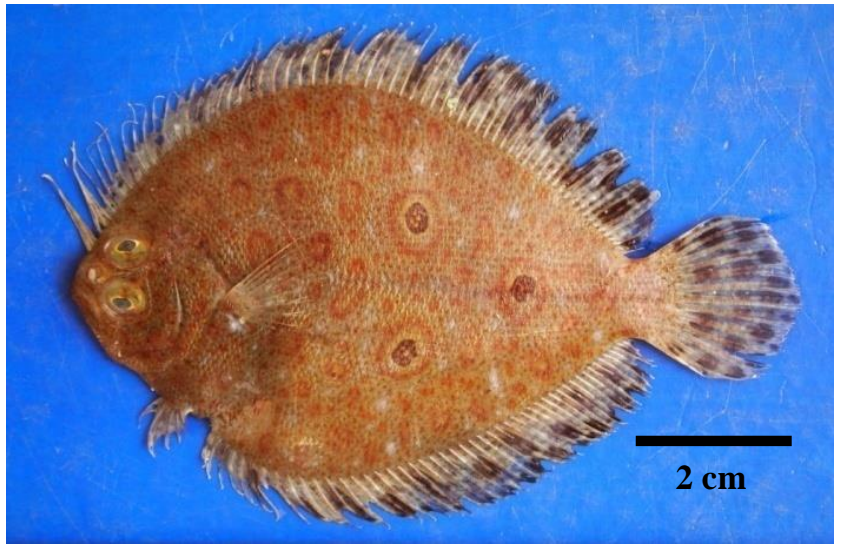

Figure 2. Pseudorhombus triocellatus (Bloch \& Schneider, 1801) collected from trawl bycatches of Parangipettai coastal waters, India

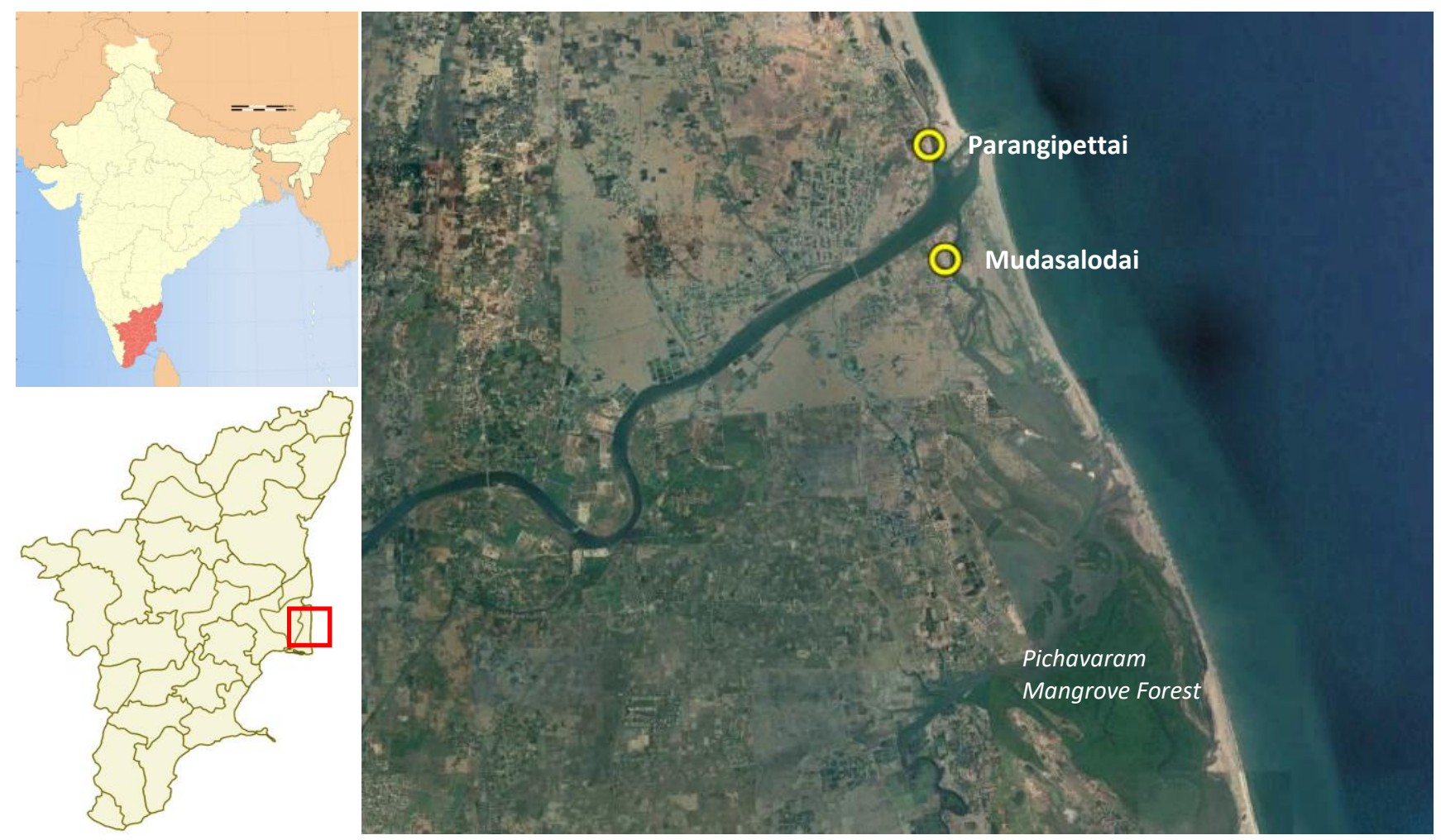

Figure 1. Geographical map of Parangipettai and Mudasalodai landing centres, Parangipettai coast, Tamil Nadu, India 


\section{Length-weight relationship (LWR)}

The length-weight relationship was calculated by following the equation $\mathrm{W}=\mathrm{aL}^{\mathrm{b}}$ (Froese, 2006). The data were examined in logarithmic plots to identify and remove outlying data points. The logarithmically transformed equation is $\log \mathrm{W}=\log \mathrm{a}+\mathrm{b} \log \mathrm{L}$, where $\mathrm{W}$ is total body weight in gram, TL is total body length in centimeter, $a$ is intercept of regression curve and b is growth coefficient related to body form. The coefficient of determination $\left(r^{2}\right)$ was estimated for each species as an indicator of the quality of linear regression.

\section{Relative condition factor}

The seasonal mean relative condition factor $(\mathrm{Kn})$ of samples was estimated by using the equation $\mathrm{Kn}=\mathrm{W}_{0} / \mathrm{W}$, where $\mathrm{Kn}$ is Fulton's condition factor, $\mathrm{W}_{0}$ is observed weight and $\mathrm{W}$ is expected weight of each size group calculated from the length-weight relationship.

\section{Age and growth estimation}

Powell-Wetherall method (Beverton and Holt 1956) was used to calculate the ratio of total mortality and growth coefficient $(\mathrm{Z} / \mathrm{K})$ as an initial estimate of asymptotic length $(\mathrm{L} \infty)$. Munro method (Munro, 1982) uses growth increment data to estimate $\mathrm{L} \alpha$ and $\mathrm{K}$.

Length frequency data were then analyzed by Electronic Length Frequency Analysis (ELEFAN I) (Pauly 1980; Pauly 1983) using the appropriate routines in FiSAT II package. In this method the growth parameters, asymptotic length $\left(\mathrm{L}_{\infty}\right)$ and growth coefficient $(\mathrm{K})$ were estimated following the von Bertalanffy growth equation (Wetherall 1986):

$$
\mathrm{L}_{\mathrm{t}}=\mathrm{L}_{\infty}\left[1-\mathrm{e}^{-\mathrm{K}\left(\mathrm{t}-\mathrm{t}_{0}\right)}\right]
$$

Where $L_{t}$ is the length at age $t, L \infty$ is the asymptotic length in $\mathrm{cm}, \mathrm{K}$ is the growth coefficient and $\mathrm{t}_{0}$ is the age at which fish would have had zero length if they had always grown according to the above equation. Parameters of $\mathrm{L}_{\infty}$ and $\mathrm{K}$ were computed from the ELEFAN I.

The $t_{0}$ value from the length-frequency data cannot be estimated by ELEFAN, $\mathrm{t}_{0}$ is estimated by substituting the $\mathrm{L}$ and $\mathrm{K}$ in the following equation: $\log \left(\mathrm{t}_{0}\right)-0.176+0.260 \log \mathrm{L} 1.0 \log \mathrm{K}$

Growth performance index was calculated by the equation (Pauly \& Munro 1984):

$\Phi=\log _{10} \mathrm{~K}+2 \log _{10} \mathrm{~L}_{\infty}$

Longevity was estimated from the following equation (Pauly 1983):

$\mathrm{t}_{\max }=3 / \mathrm{K}$

\section{RESULTS AND DISCUSSION}

The smaller fishes (4-6 cm TL) were dominant during January to March while the larger (10-13 cm TL) fishes were from September to November.

\section{Length-weight relationship (LWR)}

The total body weight of $P$. triocellatus males and females ranged from 5.26-32.84 $\mathrm{g}$ and 6.20-35.41 g, respectively. Descriptive statistics and the estimated length and weight parameters of $P$. triocellatus are presented in Table 1. The intercept of the regression curve (a) and growth coefficient (b) was approximately similar for both male and female $P$. triocellatus. The coefficient of determination $\left(\mathrm{r}^{2}\right)$ for both male and female was higher than 0.95 (Table 1). Analysis of covariance used to test the difference in regression coefficients between males and females did not reveal significant differences at 5\% level $(\mathrm{F}=0.4613, \mathrm{P}>0.05)$.

\section{Relative condition factor $(\mathrm{Kn})$}

The values of $\mathrm{Kn}$ showed wide fluctuations during various months in both males and females (Figure 3 ). The condition factor $(\mathrm{Kn})$ of male varied between 0.76 and 1.01 whereas in females it varied between 0.80 and 1.08. The maximum condition factor $(\mathrm{Kn})$ values for males and females were recorded during September and October, respectively. In both sexes, the condition factor was found minimum during April. Two-way ANOVA of males ( $\mathrm{F}=$ $1.21 ; \mathrm{P}<0.5)$ and females $(\mathrm{F}=1.47 ; \mathrm{P}<0.5)$ indicated significant differences in $\mathrm{Kn}$ values between various months.

Table 1. Length-weight relationship parameters of Pseudorhombus triocellatus collected from Mudasalodai landing center during January-December 2015, India

\begin{tabular}{|c|c|c|c|c|c|c|}
\hline \multirow[b]{2}{*}{ Species } & \multirow[b]{2}{*}{$\mathbf{n}$} & \multirow{2}{*}{$\begin{array}{l}\text { Total Length } \\
\text { (cm) }\end{array}$} & \multirow{2}{*}{$\begin{array}{l}\text { Weight } \\
\text { (g) }\end{array}$} & \multicolumn{3}{|c|}{ Regression parameters } \\
\hline & & & & $\begin{array}{c}\mathbf{a} \\
(95 \% \mathrm{CI})\end{array}$ & $\begin{array}{c}\text { b } \\
(95 \% \mathrm{CI})\end{array}$ & $\mathbf{r}^{2}$ \\
\hline Male & 360 & $4.0-12.6$ & $5.26-32.84$ & $\begin{array}{c}0.0140 \\
(0.0134-0.0156)\end{array}$ & $\begin{array}{c}2.797 \\
(2.567-3.027)\end{array}$ & 0.953 \\
\hline Female & 399 & $4.4-13.0$ & $6.20-35.41$ & $\begin{array}{c}0.0250 \\
(0.0222-0.0278) \\
\end{array}$ & $\begin{array}{c}3.023 \\
(2.913-3.133)\end{array}$ & 0.969 \\
\hline
\end{tabular}

Notes: $\mathrm{n}=$ sample size, $\mathrm{a}=$ intercept of regression curve, $\mathrm{b}=$ growth coefficient, $\mathrm{r}^{2}=$ determination coefficient, $95 \% \mathrm{CI}=95 \%$ Confidential Interval 


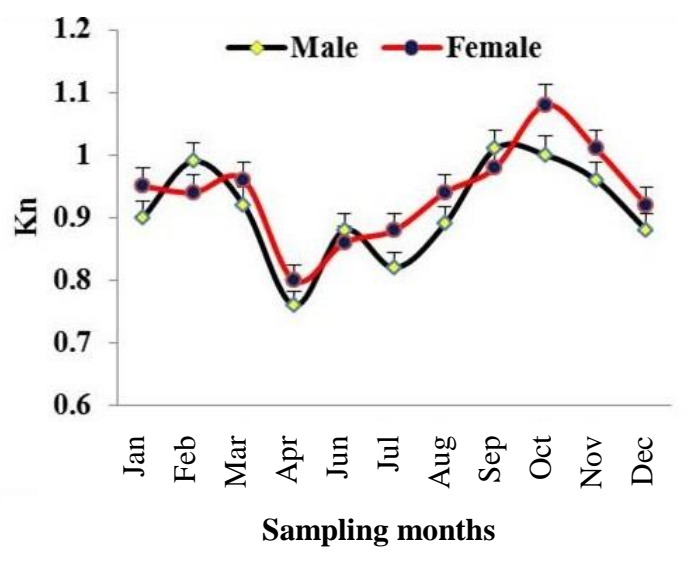

Figure 3. Relative condition factor (Kn) (Mean and Standard Error) of male and female of Pseudorhombus triocellatus from Parangipettai Coast, India

\section{Age and growth estimation}

The Powell-Wetherall plots estimated the $\mathrm{L}_{\max }$ and $\mathrm{Z} / \mathrm{K}$ (the ratio of the coefficients of mortality and growth) value of males and females of $P$. triocellatus as $137.11 \mathrm{~mm}$ and $139.12 \mathrm{~mm}, 1.439 \mathrm{yr}^{-1}$ and $1.516 \mathrm{yr}^{-1}$, respectively (Figure

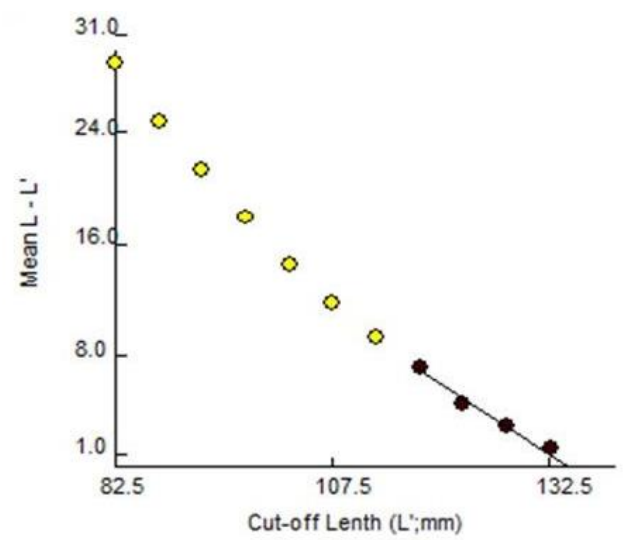

$\mathbf{A}$
4). The Munro plots estimated the asymptotic lengths and $\mathrm{K}$ values for males and females of $P$. triocellatus as 137.11 $\mathrm{mm}$ and $141.75 \mathrm{~mm}, 3.431 \mathrm{yr}^{-1}$ and $6.167 \mathrm{yr}^{-1}$, respectively (Figure 5).

The results of optimized growth parameters ( $\mathrm{L} \alpha$ and $\mathrm{K}$ ) and the goodness of fit index $(\mathrm{Rn})$ for males and females of $P$. triocellatus estimated by ELEFAN I method are shown in Table 2 and Figure 6 . The K-Scan routines estimated the $\mathrm{L} \alpha$ and $\mathrm{K}$ value for males as $137.11 \mathrm{~mm}$ and $1.60 \mathrm{yr}^{-1}$ and for females as $141.75 \mathrm{~mm}$ and $1.77 \mathrm{yr}^{-1}$, respectively.

Table 2. Growth parameters of males and females of Pseudorhombus triocellatus obtained from different methods by using length frequency data

\begin{tabular}{llllll}
\hline Method & Sex & $\mathbf{L}_{\infty}(\mathbf{m m})$ & $\mathbf{Z} / \mathbf{K}$ & $\begin{array}{l}\mathbf{K} \\
\left(\mathbf{y r}^{-1}\right)\end{array}$ & $\mathbf{R n} /$ score \\
\hline Powell wetherall & M & 137.11 & 1.439 & - & - \\
& $\mathrm{F}$ & 139.12 & 1.516 & - & - \\
ELEFAN I & & & & & \\
(i) Automatic search & $\mathrm{M}$ & 141.75 & - & 1.60 & 0.317 \\
& $\mathrm{~F}$ & 141.85 & - & 1.70 & 0.425 \\
(ii) K-scan & $\mathrm{M}$ & 137.11 & - & 1.60 & - \\
& $\mathrm{F}$ & 141.75 & - & 1.77 & - \\
\hline
\end{tabular}

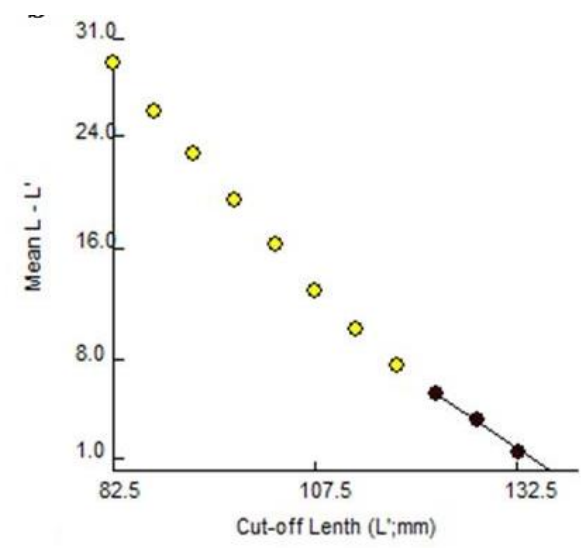

B

Figure 4. Powell-Wetherall plot of male (A) and female (B) of Pseudorhombus triocellatus from Parangipettai Coast, India

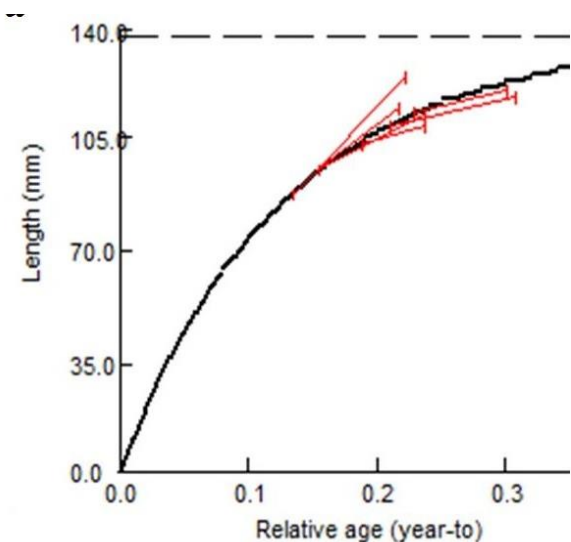

A

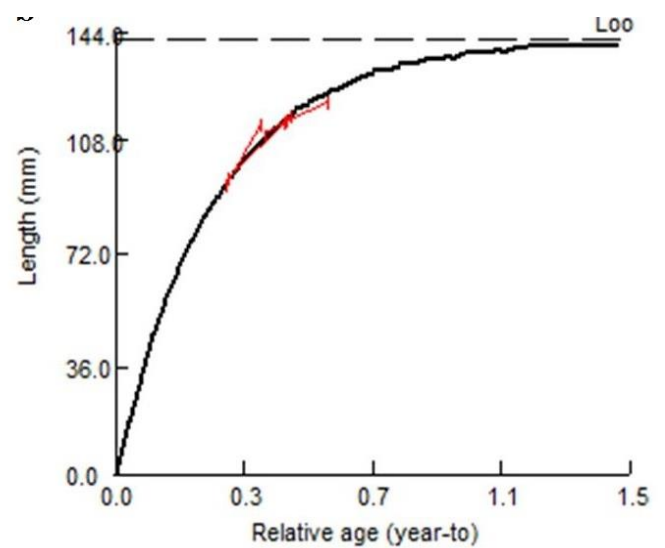

B

Figure 5. Munro's plot of male (A) and female (B) of Pseudorhombus triocellatus from Parangipettai Coast, India 


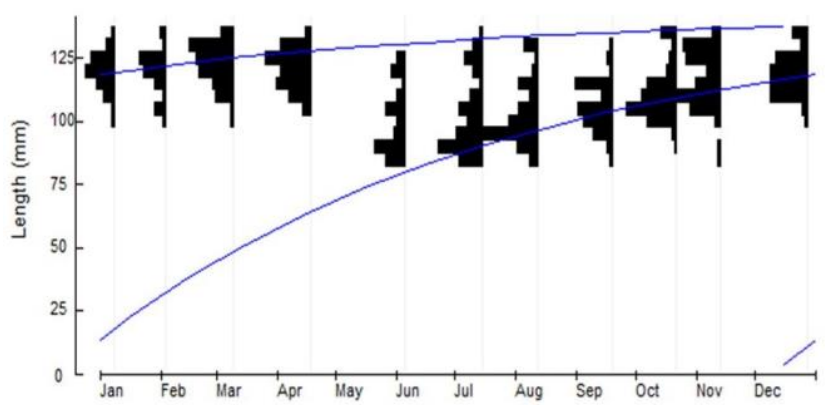

A

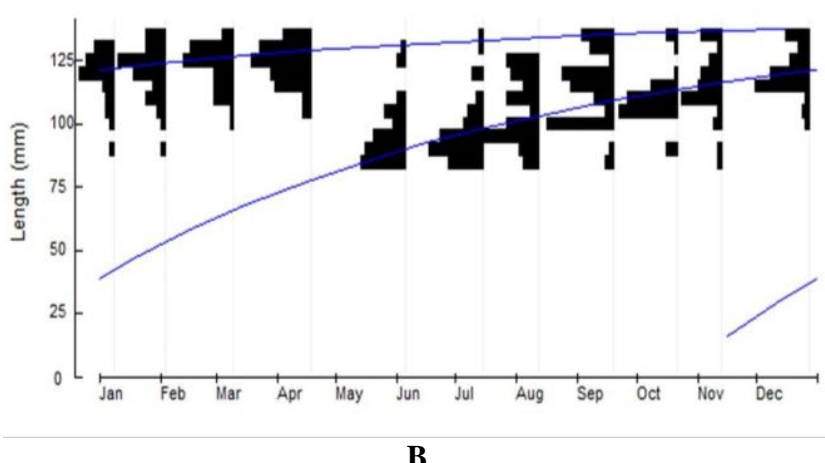

Figure 6. ELEFAN I growth curve of male (A) and female (B) of Pseudorhombus triocellatus from Parangipettai Coast, India

These initial estimates were fed into ELEFAN I package for estimation of optimum growth of $P$. triocellatus. The best optimum value of VBGF growth constant $(\mathrm{K})$ for males and females were $0.397 \mathrm{yr}^{-1}$ and $0.410 \mathrm{yr}^{-1}$, respectively and similarly, the estimated $\mathrm{t}_{0}$ values for males and females were $0.197 \mathrm{~mm}$ and 0.292 mm, respectively (Tables 3 ; Figure 7).

The estimated growth performance index $(\Phi)$ values for males and females were 2.042 and 2.140 , respectively. Also, the estimated longevity $\left(\mathrm{t}_{\max }\right)$ of males and females of $P$. triocellatus were 2.04 and 2.24 years, respectively.

\section{Discussion}

From the regression equation obtained in the present study, it is clear that the (b) values (growth coefficient related to body form) traced for males (2.797) and females (3.023) did not show significant differences $(\mathrm{P}>0.05)$. Froese et al. (2014) estimated the Bayesian LWR of $P$. triocellatus as $\mathrm{a}=0.00776(0.00365-0.01649), \mathrm{b}=3.14$ $(2.96-3.32) \mathrm{cm}$ TL, based on the LWR estimates for this family-body shape. Hashemi et al. (2013) reported a similar growth pattern in Pseudorhombus elevatus (b value of male 2.90, female 3.09 and 3.04 of both male and female together) from Khuzestan coastal waters, Iran. Aghajanpour et al. (2014) estimated positive allometric growth pattern in $P$. elevatus (b value of both male and female together $=3.290$ ) from intertidal and coastal waters in the northern Persian Gulf. Pouladi et al. (2017) also recorded positive allometric growth pattern in $P$. elevates from Iranian coastal waters $\left(\mathrm{W}=0.006 \mathrm{TL}^{3.181}\right)$.

Abdurahiman et al. (2004) predicted values of the exponent (b) of large tooth flounder, $P$. arsius from India (males $\mathrm{b}=3.256 \mathrm{TL}$ and females $3.378 \mathrm{TL}$ ) and similarly Human and Al-Busaidi (2008) recorded b values (3.1671 TL) f $P$. arsius from Arabian Sea Coast of Oman. Kwak and Park (2015) reported that the values of exponent $b$ for six flounder species (Paralichthys olivaceus, Cleisthenes pinetorum, Glyptocephalus stelleri, Platichthys stellatus, Pseudopleuronectes herzensteini, and $P$. yokohamae) ranged from 3.076 to 3.469 from the eastern coast of Korea. The difference in growth pattern between both sexes might be due to a series of factors such as environmental conditions, habitat, gonad maturity, diet, stomach fullness and health (Bagenal and Tesch 1978).

Table 3. Estimation of $\mathrm{K}$ and to with the von Bertalanffy plot for male and female of Pseudorhombus triocellatus from Parangipettai Coast, India

\begin{tabular}{cccccccc}
\hline Age & $\begin{array}{c}\text { Length } \\
(\mathbf{L t}) \\
(\mathbf{m m})\end{array}$ & $\begin{array}{c}\mathbf{L t} / \\
\mathbf{L} \infty\end{array}$ & $\begin{array}{c}\mathbf{1 -} \\
\mathbf{L t} / \mathbf{L} \infty\end{array}$ & $\begin{array}{c}-\mathbf{L N}(\mathbf{1 - t} / \mathbf{L}) \\
\mathbf{L} \boldsymbol{})\end{array}$ & $\begin{array}{c}\mathbf{K = b} \\
\left(\mathbf{y r}^{-\mathbf{1}}\right)\end{array}$ & $\begin{array}{c}\mathbf{t}_{\mathbf{0}} \\
(-\mathbf{- a} / \mathbf{b}) \\
(\mathbf{m m})\end{array}$ \\
\hline Male & 1 & 80 & 0.5463 & 0.4357 & 0.8308 & 0.397 & 0.197 \\
& 2 & 120 & 0.8465 & 0.1535 & 1.8741 & & \\
Female & 1 & 78 & 0.5498 & 0.4502 & 0.7982 & 0.410 & 0.292 \\
& 2 & 123 & 0.8671 & 0.1329 & 2.0181 & & \\
\hline
\end{tabular}

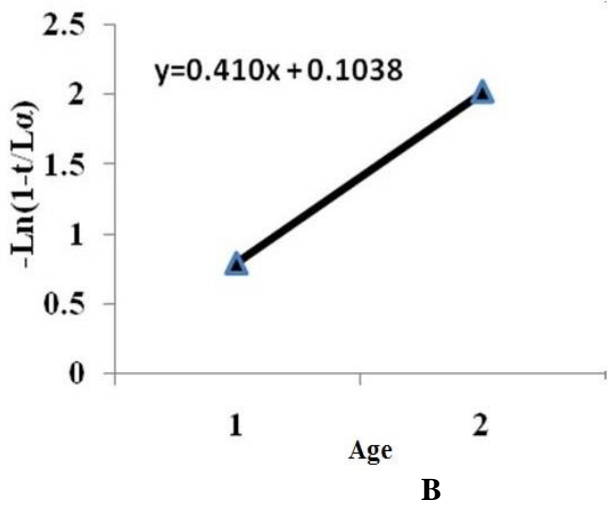

Figure 7. Von Bertalanffy plot of male (A) and female (B) of Pseudorhombus triocellatus from Parangipettai Coast, India 
In the present study, the relative condition factor $(\mathrm{Kn})$ values of females were found higher than males throughout the year except during February, June, and September. According to Le Cren (1951), the relative condition factor $(\mathrm{Kn})$ is an indicator of the general well-being of the fish. $\mathrm{Kn}$ value greater than one is indicative of the good condition, whereas the value less than one stands for not in good condition. Kn values of the present study, varied between 0.76 and 1.08 in both the sexes. The increased trend in relative condition factor in both males and females during July-October and sudden decreased during AprilJune might be related to the maturation of these fishes. It was closely related to the spawning season of $P$. triocellatus which generally occurs during August-October (Ramanathan et al. 1990). The Kn values obtained in the present study revealed that the health of $P$. triocellatus in Parangipettai waters was in good condition during the study period.

In the present study, values of $\mathrm{L}_{\infty}$ for both sexes agreed well with observed lengths. The largest male collected in this study was $12.6 \mathrm{~cm}$, and the calculated $\mathrm{L}_{\infty}$ for males was $13.7 \mathrm{~cm}$. The largest female collected in this study was $13 \mathrm{~cm}$ and the calculated $\mathrm{L}_{\infty}$ for females was $14.1 \mathrm{~cm}$. These results are acceptable because the asymptotic length is a regression estimate and it represents maximum length if fish live and grow according to the von Bertalanffy equation.

The Estimates of the present study on the growth parameters were found similar to the reports done by previous researchers from elsewhere. $\mathrm{L}_{\infty}$ values obtained for Paralichthys isosceles by Cousseau (1990) were 32.64 $\mathrm{cm}$ for males and $35.39 \mathrm{~cm}$ for females from the Argentinian coast. Araújo and Haimovice (2000) estimated the $\mathrm{L}_{\infty}$ value of males and females of $P$. patagonicus were 53.4 and $62.3 \mathrm{~cm}$, respectively from southern Brazil coast. Jimenez et al. (2001) reported the $\mathrm{L}_{\infty}$ values of males and females of wedge sole from Spanish waters as $24.0 \mathrm{~cm}$ and $27.0 \mathrm{~cm}$, respectively. Cabrel et al. (2003) reported that the growth parameters of Synaptura lusitanica differed marginally between both sexes from the Portuguese coast, the asymptotic length obtained for females were little higher compared to males. Dwyer et al. (2003) derived $\mathrm{L}_{\infty}$ and $\mathrm{K}$ values of yellowtail flounder as $556 \mathrm{~mm}$ and $0.16 \mathrm{yr}^{-}$ ${ }^{1}$ (for both male and female together) the Grand Bank off Newfoundland. Kume et al. (2006) found that the mean back-calculated length for females at each estimated age was greater than males of the marbled sole, Pleuronectes yokohamae. Hashemi et al. (2013) estimated the $\mathrm{L}_{\infty}$ $(42 \mathrm{~cm}), \mathrm{K}$ values $\left(1 \mathrm{yr}^{-1}\right)$ and $\mathrm{Rn}$ value $(0.178)$ of Pseudorhombus elevatus from Khuzestan coastal waters, Iran.

The best optimum value of VBGF growth constant (K) recorded in this study was found higher than other flatfishes. The estimated $\mathrm{K}$ value of males and females of $P$. isosceles were $0.359 \mathrm{yr}^{-1}$ and $0.313 \mathrm{yr}^{-1}$ (Cousseau 1990); for Cynoglossus arel males $0.238 \mathrm{yr}^{-1}$ and for females $0.315 \mathrm{yr}^{-1}$ (Rajaguru 1992); for P. patagonicus males $0.214 \mathrm{yr}^{-1}$ and for females $0.279 \mathrm{yr}^{-1}$ (Julio and Manuel 2000 ). Karen et al. (2003) reported the K value of
Limanda jerruginea as $0.16 \mathrm{yr}^{-1}$. Amezcua et al. (2006) reported a low $\mathrm{K}$ value $(0.245)$ for Cyclopsetta querna. The estimated growth coefficient of $P$. triocellatus showed comparatively higher (for males $0.397 \mathrm{yr}^{-1}$ and for females $0.410 \mathrm{yr}^{-1}$ ) growth rate. Pauly (1984) reported that species having shorter life have higher $\mathrm{K}$ value and reach their $\mathrm{L}_{\infty}$ within one or two years. On the other hand, those having lower $\mathrm{K}$ values take comparatively higher duration to reach their $\mathrm{L}_{\infty}$. The results obtained (K values and $\mathrm{L}_{\infty}$ ) for $P$. triocellatus was found in agreement with the relationship reported by Pauly (1984).

The present study indicated shorter life span lifespan for males and females of $P$. triocellatus and the estimated lifespan of $P$. triocellatus males and females were 2.04 and 2.24 years, respectively. The longevity of $P$. elevatus was estimated to be 3.24 year in Iranian coastal waters (Hashemi et al. 2013) and similarly, for P. pentophtalmus, it was estimated to be 3 years (Minami and Tanaka 1992). Cabrel et al. (2003) estimated the longevity of Synaptura Lusitania to be 8 years in Portuguese coastal waters. Sano et al. (1987) reported the life span of Limand yokohamae to be 5 years for males and 6 years for females. Vassilopoulou and Papaconstan (1994) reported the maximum life span $\left(t_{\max }\right)$ of males and females of Citharus linguatula to be 5 years and 7 years, respectively. Andrea (2005) estimated the $t_{\max }$ of males and females of Paralichthys orbignyanus 6 years and 7 years, respectively. Amezcua et al. (2006) reported the longevity of Cyclopsetta quernna was 5 years. The maximum age of Pleuronectes yokohamae males and females were 5 years and 6 years, respectively (Gen et al. 2006).

The estimated growth performance index $(\Phi)$ values for males and females of $P$. triocellatus were 2.042 and 2.140, respectively and similarly, the $\mathrm{t}_{0}$ values estimated for males and females of $P$. triocellatus were $0.197 \mathrm{~mm}$ and 0.292 $\mathrm{mm}$, respectively. Hashemi et al. (2013) estimated the growth performance index $(\Phi)$ and $t_{0}$ values of $P$. elevatus as 3.24 and $-0.14 \mathrm{~mm}$ by using the von Bertalanffy method from Iranian coastal waters. The negative $t_{0}$ value reflects that the juveniles grew more quickly than the predicted growth curve for adults and the positive $t_{0}$ values reflect that the juveniles grew more slowly (Sparre and Venema 1998).

This study updates the length-weight relationship, age, and growth of three-spotted flounder, Pseudorhombus triocellatus from Parangipettai coastal waters. This fish was found healthy and it showed $2^{+}$year of age in this region. The results of growth parameters obtained in the present study will be used for stock assessment of this species.

\section{ACKNOWLEDGEMENTS}

The authors wish to thank the Director and Dean, CAS in Marine Biology and authorities of Annamalai University, India for providing the necessary facilities. 


\section{REFERENCES}

Abdurahiman KP, Nayak TH, Zacharia PU, Mohamed K. 2004. Lengthweight relationship of commercially important marine fishes and shellfishes of the southern coast of Karnataka, India. NAGA World Fish Ctr Q 27 (1-2): 9-14.

Abowei JFN, Davies OA, Eli AA. 2009. Study of the length-weight relationship and condition factor of five fish species from Nkoro River, Niger Delta, Nigeria. Res J Biol Sci 1 (3): 94-98.

Aghajanpour M, Raeisi H, Moradinasab A, Daliri M, Parsa M, Bibak M, Nekuru A. 2015. Length-weight relationships of six fishes from intertidal and coastal waters in the northern Persian Gulf. J Appl Ichthyol 31 (2): 403-404.

Amezcua F, Martínez-Tovar I, Green-Ruiz Y, Amezcua-Linares F. 2006 Use of otoliths to determine age and growth of a tropical flatfish Cyclopsetta querna (Paralichthyidae) from the southeast coast of the Gulf of California, Mexico. Ichthyol Res 53 (1): 70-74.

Araújo JND, Haimovice M. 2000. Age and growth of the white flounder Paralichthys patagonicus (Jordan, 1889) in southern Brazil. Brazilian J Oceanogr 48 (1): 61-70.

Bagenal TB, Braum H. 1978. Eggs and early life history. In: Bagenal TB (ed.). Methods for Assessment of Fish Production in Freshwaters. Blackwell Scientific, Oxford.

Beverton RJH, Holt SJ. 1956. A review of methods for estimating mortality rates in fish populations, with special reference to sources of bias in catch sampling. Rapp Proces-verb Reun Cons Int Explor Mer 140: 67-83.

Bijukumar A, Deepthi GR. 2009. Mean trophic index of fish fauna associated with trawl bycatch of Kerala, southwest coast of India. J Mar Biol Assoc India 51 (2): 145-154.

Cabral H, Catarino AI, Figueiredo J, Garcia J, Henriques M. 2003. Feeding ecology, age, growth and sexual cycle of the Portuguese sole, Synaptura lusitanica. J Mar Biol Assoc UK 83 (3): 613-618.

Cazorla AL. 2005. On the age and growth of flounder Paralichthys orbignyanus (Jenyns, 1842) in Bahía Blanca Estuary, Argentina. Hydrobiologia 537 (1-3): 81-87.

Christensen V, Walters CJ. 2004. Ecopath with Ecosim: methods, capabilities and limitations. Ecol Model 172 (2-4): 109-139.

Cousseau MB, Perrotta R. 1998. Peces marinos de Argentina. Biología, distribución, pesca (No. M11 INIDEP 16953; CD 2 (2000)). Instituto Nacional de Investigación y Desarrollo Pesquero (INIDEP), Mar del Plata, Argentina.

Dwyer KS, Walsh SJ, Campana SE. 2003. Age determination, validation and growth of Grand Bank yellowtail flounder (Limanda ferruginea). ICES J Mar Sci 60 (5): 1123-1138.

Fournier DA, Sibert JR, Majkowski J, Hampton J. 1990. MULTIFAN - A likelihood-based method for estimating growth parameters and age composition data sets illustrated by using data for Southern blue fin tuna (Thunnus maccoyii). Can J Fish Aquat Sci 47 (2): 301-317.

Froese R. 2006. Cube law, condition factor and weight-length relationships: history, meta-analysis and recommendations. J Appl Ichthyol 22 (4): 241-253.

Froese R, Thorson JT, Reyes JrRB. 2014. A Bayesian approach for estimating length-weight relationships in fishes. J Appl Ichthyol 30 (1): $78-85$

Gayanilo JrFC, Soriano M, Pauly D. 1988. A draft guide to the Compleat ELEFAN. ICLARM Software Project and diskettes 2. International Center for Living Aquatic Resources Management, Penang, Malaysia

Gayanilo JrFC, Pauly D. 1997. The FAO-ICLARM Stock Assessment Tools (FiSAT) Reference manual. FAO Computerized Information Series (Fisheries), FAO, Rome.

Hashemi SAR, Taghavimotlagh SA, Ghorbani R, Hedayati A. 2013 Population parameters and length-weight relationship of deep flounder (Pseudorhombus elevatus) in northwest of Persian Gulf (Khuzestan coastal waters, Iran). J Mar Sci Eng 3 (1): 1-6.

Human BA, Al-Busaidi H. 2008. Length and Weight Relationships for 31 Species of Fishes Caught by Trawl from Arabian Sea Coast of Oman. J Agr Mar Sci 13: 43-52.

Jiménez MP, Piñeiro C, Sobrino I, Ramos F. 2001. Studies on age determination and growth pattern of the wedge sole Dicologoglossa cuneata (Moreau, 1881) in the Spanish waters of the Gulf of Cadiz (southwest Iberian Peninsula). Bol Inst Esp Oceanogr 17 (3/4): 279286.

King RP. 1996. Length-weight relationships of Nigerian coastal water fishes. Naga ICLARM Q 19 (4): 53-58.

Kirkwood GP, Auckland R, Zara SJ. 2001. Length Frequency Distribution Analysis (LFDA), Version 5, MRAG Ltd. London, U.K.

Kume G, Horiguchi T, Goto A, Shiraishi H, Shibata Y, Morita M, Shimizu M. 2006. Seasonal distribution, age, growth, and reproductive biology of marbled sole Pleuronectes yokohamae in Tokyo Bay, Japan. Fish Sci 72 (2): 289-298.

Kwak SN, Park JM. 2016. Length-weight and length-length relationships for six flounder species (Pleuronectiformes) from the eastern coast of Korea. J Appl Ichthyol 32 (1): 160-162.

Laidig TE, Pearson DE, Sinclair LL. 2003. Age and growth of blue rockfish (Sebastes mystinus) from central and northern California. Fish Bull 101 (4): 800-808.

Le Cren ED. 1951. The length-weight relationship and seasonal cycle in gonad weight and condition in the perch (Perca fluviatitlies). J Anim Ecol 20: 201-239.

Mendes B, Fonseca P, Campos A. 2004. Weight-length relationships for 46 fish species of the Portuguese west coast. J Appl Ichthyol 20 (5): 355-361.

Minami T, Tanaka M. 1992. Life history cycles in flatfish from the northwestern Pacific, with particular reference to their early life histories. Neth J Sea Res 29 (1-3): 35-48.

Mohanraj G. 2000. Studies on the Biology and Population Dynamics of the Goatfishes (Pisces: Mullidae), Upeneus bensasi and Upeneus moluccensis of Madras coast [Dissertation]. University of Madras, India.

Munro JL. 1982. Estimation of the parameters of the von Bertalanffy growth equation from recapture data at variable time intervals. ICES J Mar Sci 40: 199-200.

Oscoz J, Campos F, Escala MC. 2005. Weight-length relationships of some fish species of the Iberian Peninsula. J Appl Ichthyol 21 (1): 7374.

Panfili J, de Pontual H, Troadec H, Wright PJ. 2002. Manual of fish Sclerochronology. Ifremer-IRD co-edition, Brest, France.

Pauly D. 1980. A selection of simple methods for the assessment of tropical fish stocks. FAO Fisheries \& Aquaculture, Rome.

Pauly D, Munro JL. 1984. Once more on the comparison of growth in fish and invertebrates. Fishbyte 2-1: 21.

Pauly D. 1993. Editorial, Fish byte. Naga ICLARM Q 16 (2-3): 26

Pouladi M, Moradinasab A, Paighambari SY, Daliri M, Raeisi H, Shabani MJ. 2018. Length-weight relationships of three caught flatfish using shrimp trawler in Motaf fishing grounds, Bushehr province (Persian Gulf). J Appl Ichthyol 34 (3): 750-752.

Rajaguru A. 1992. Biology of two co-occurring tonguefishes, Cynoglossus arel and $C$. lida (Pleuronectiformes: Cynoglossidae), from Indian waters. Fish Bull 90 (2): 328-367.

Ramanathan N, Venkataramani VK, Venkataramanujam K. 1990. Breeding biology of flatfish Pseudorhombus triocellatus (Bloch and Schn.) from Tuticorin waters, east coast of India. Indian J Mar Sci 19 (2): 151-152.

Richter H, Luckstadt C, Focken U, Becker K. 2000. An improved procedure to assess fish condition on the basis of length-weight relationships. Arch Fish Mar Res 48 (3): 255-264.

Sparre P. 1987. Computer programs for fish stock assessment. Lengthbased fish stock assessment for Apple II computers. FAO Fish. Tech. Pap. 101. Suppl., 2, p. 218, FAO, Rome.

Sparre P, Venema SC. 1998. Estimation of Growth Parameters. Introduction of Tropical Fish Stock Assessment. Part 1. Manual, FAO Fisheries Technical Paper, 306. No. 1, Review 1, FAO, Rome.

Sujatha K. 1995. Finfish constituents of trawl by-catch off Visakhapatnam. Fish Technol 32: 56-56.

Vassilopoulou V, Papaconstantinou C. 1994. Age, growth and mortality of the spotted flounder (Citharus linguatula Linnaeus, 1758) in the Aegean Sea. Sci Mar 58 (3): 261- 267.

Wetherall JA. 1986. A new method for estimating growth and mortality parameters from length-frequency data. ICLARM Fishbyte 4 (1): 1214. 